\title{
An Econometric Model of the South African Stock Market
}

\author{
Elna Moolman
}

Standard Bank ${ }^{1}$

Charlotte du Toit

Department of Economics, University of Pretoria

A wealth of literature exists concerning the modelling of stock markets, as well as the examination of the relationship between share prices and various economic factors, both theoretically and empirically. However, most studies use data for developed countries in their analyses, while the literature modelling emerging stock markets in general, and the South African stock market in particular, is quite sparse. This study develops a structural, theoretically founded model of the South African stock market that is estimated using co-integration and error-correction techniques. These techniques respectively estimate the long-term equilibrium level or intrinsic value of the stock market, and the short-term fluctuations around the equilibrium level. According to the results, share prices are co-integrated with the variables dictated by the expected present value model of asset price determination. The short-term fluctuations are determined by various factors such as interest rates, a risk premium, the exchange rate, foreign stock markets and other variables.

JEL C22, G10

\section{1}

\section{Introduction}

A wealth of literature exists concerning the modelling of stock markets as well as the examination of the relationship between share prices and various economic factors, both theoretically and empirically. However, most studies use data for developed countries in their analyses, while the literature modelling emerging stock markets, particularly the South African stock market, is sparse. The most important studies analysing the structural determinants of the Johannesburg Stock Exchange (JSE) are those of Van Rensburg (1995, 1998, 1999) and Barr and Kantor (2002). Van Rensburg studied the bivariate relationships between the JSE and economic variables, while Barr and Kantor developed an econometric model of the South African economy, focusing on the linkages between the real and financial markets and between domestic and foreign financial markets. However, no structural, theoretically founded model of the South African stock market has yet been developed and estimated.

In this study, a structural model of the South African stock market, the Johannesburg Stock Exchange (JSE), will be estimated using cointegration techniques and error correction modelling. The intention with the model is to expose the macro-economic variables that influence the stock market, as well as the magnitudes of these impacts. This model will have three main uses. Firstly, the stock market is widely regarded as a leading indicator of economic activity as it reflects investors' expectations of future economic conditions. The model developed in this study could therefore potentially be used to predict the stock market and hence give an indication of the direction of the aggregate economy. Secondly, the econometric model will empirically 
estimate and evaluate the relationships between the stock market and macro-economic variables. This ought to improve the general understanding of all economic agents of the stock market, as well as the relationships between the stock market and macro-economic variables. In addition, it could also be useful to investors for designing trading rules based on structural relationships, which ought to improve profits in the long term.

A third use of a stock market model is to evaluate the importance of fundamentals in determining South African stock prices. The so-called 'contagion' effect between international stock markets has received considerable attention in recent literature, especially since the emerging market crises. However, if the stock market is found to be driven in the long term by fundamental domestic factors, it means that contagion influences only short-term fluctuations and not the long-term level or intrinsic value of the stock market. This issue is very important, as it has crucial implications for the role of stock markets in the broader economic development process. Stock markets can support the process of economic development by increasing the growth in savings, and improving the efficient allocation and utilisation of investment resources (Lee, 1997). However, stock markets can only fulfil these roles if they are being driven by economic fundamentals, so that their pricing and allocation of capital within the economy properly reflect risk and expected returns. If stock markets are not economically efficient in the broad sense of allocating financial capital efficiently to competing uses, they are unlikely to make a positive contribution to economic development, but would more closely resemble gambling (Jefferis \& Okeahalam, 2000). The only way in which these relationships can be evaluated is by estimating an empirical model that can distinguish between the long-term determinants and the short-term dynamics of the stock market.

This study makes three contributions to the literature: it empirically evaluates the role of economic fundamentals in the behaviour of share prices in South Africa; it estimates a theoretically founded empirical model of the South African stock market; it establishes the factors that influence the stock market in the long and short term and then finally quantifies these impacts.

The study is organised as follows: the next section gives a description of the Johannesburg Stock Exchange (JSE); section three describes the theoretical background; section four summarises the literature on stock market modelling; the empirical results are presented in section five; and the conclusion in section six.

2

\section{Description}

The Johannesburg Stock Exchange (JSE) was founded in November 1887, 14 months after the proclamation of the Witwatersrand Goldfields, to enable the new mines and their financiers to raise capital for the development of the mining industry. Both the number and type of companies listed on the JSE have changed dramatically over the years. As the economy expanded and developed, the mining companies that were initially listed on the JSE were joined by an increasing number of industrial companies that listed on the JSE. Today most of the companies listed on the JSE are non-mining companies. The rapid growth of the JSE is reflected in the growth of the number of listed companies that grew from only 151 mining, financial and industrial companies listed in 1932, to 659 companies in 1998 (see Table 1). The rapid growth is also evidenced from the necessity to relocate to bigger buildings six times within 90 years. 
Table 1

Characteristics of the JSE

\begin{tabular}{|l|r|r|r|r|r|}
\hline Characteristic & \multicolumn{1}{|c|}{$\mathbf{1 9 8 5}$} & \multicolumn{1}{|c|}{$\mathbf{1 9 9 0}$} & $\mathbf{1 9 9 5}$ & $\mathbf{1 9 9 8}$ & $\mathbf{2 0 0 2}$ \\
\hline Number of stocks listed & 462 & 732 & 640 & 668 & 852 \\
\hline Market capitalisation (R m) & 141,785 & 350,26 & $1,022,656$ & $1,001,556$ & $1,584,100$ \\
\hline Market capitalisation (US\$ m) & 55,439 & 137,540 & 280,526 & 170,252 & 181,998 \\
\hline Annual trading value (R m) & 6,241 & 21,130 & 63,237 & 323,682 & 808,662 \\
\hline Annual trading value (US\$ m) & 2,836 & 8,158 & 17,048 & 58,444 & 92,949 \\
\hline Market index & 1,323 & 2,720 & 6,228 & 5,431 & 10,288 \\
\hline
\end{tabular}

Sources: Jefferis and Okeahalam (2000) and www.jse.co.za

The mushrooming of listed companies worldwide during the 1980s also took place on the JSE and necessitated the creation of two new categories of shares, namely the Development Capital Market (DCM), which caters for smaller companies and have fewer requirements in terms of profits and company size and the Venture Capital Market (VCM) on which accepted companies undertaking greenfield ventures can be listed provided they meet certain requirements (Van Zyl et al., 2003: 288). In addition, the JSE announced the first exchange in Africa that will list small and medium-sized growth companies, the AltX (www.jse.co.za and www.altx.co.za) ${ }^{2}$. The purpose of AltX is to create an alternative exchange where small companies can raise capital in order to stimulate the small and medium enterprises (SMEs).

The reintegration of South Africa into the world economy after the abolishment of sanctions and the 1994 democratic elections had a substantial impact on the JSE. Like the rest of the economy, the JSE was also caught up in this process of reintegration, and it has become deeply entangled in the globalised trading environment characterised by 24 -hour share trading. This has made the JSE more susceptible to the influence of events and trends in the rest of the world, especially those in other emerging market economies (Van Zyl et al., 2003). The JSE has benefited from huge capital inflows to South Africa since 1994, but these were mostly portfolio flows, which increased its vulnerability to international events and sentiment, as was evident during the recent emerging market crisis.

Since the reintegration of South Africa into the world economy, foreign investors have played a more substantial role on the JSE. Total foreign investment now accounts for more than 20 per cent of the market capitalisation of the JSE, and foreign investors sometimes account for more than half of its daily trading ${ }^{2}$ (Van Zyl et al., 2003: 305). Several factors contributed to this phenomenon (Van Zyl et al., 2003: 305): (i) foreign confidence was boosted by the abolition of exchange controls in March 1995, when foreign investors gained unrestricted access to shares on the JSE. Since South Africa's abolition of exchange controls on foreigners in 1995, foreign investors have been net buyers in excess of R9.3 billion, compared to only R0.185 billion in 1994; (ii) Foreign investors have also welcomed the scrapping of the 15 per cent non-resident shareholders' tax in October 1995; (iii) Many investors who had previously left South Africa due to their disagreement with the political regime returned with the introduction of the new political dispensation in 1994; and (iv) Owing to the relative volatility of the JSE, foreign investors welcome the development of financial instruments such as futures and options markets in the rand and share indices in South Africa, which enable them to hedge currency and equity risks. 
3

\section{Theoretical background}

Two theoretical models, the efficient market hypothesis and the present value model, dominate the literature on stock market modelling. The efficient market hypothesis asserts that stock prices adjust rapidly and without bias to reflect new and relevant pricesensitive information. Initially, most of the empirical research on the efficient market hypothesis was done in terms of the random walk theory, which was based on empirical analysis without a theoretical foundation. Fama (1970) presented the first synthesis of the efficient market theory in terms of the fair game model, and Samuelson (1965) and Mandelbrot (1963) showed that the fair game model is analytically equivalent to the expected present value theory of security valuation (also called the present value model). According to this theory, stock prices are a function of all the expected future dividends discounted at the discount rate.

\subsection{The efficient market hypothesis (EMH)}

The efficient market hypothesis holds that prices adjust rapidly and without bias to new and relevant price-sensitive information. While these price adjustments are not always correct, they are unbiased, such that the under- and overadjustments are unpredictable. As new information is random and independent and the large number of investors adjust stock prices rapidly to reflect this new information, price changes are independent and random (Reilly, 1989: 212). The efficient market hypothesis has crucial implications for stock market investors and their approach to stock market trading. If capital markets are efficient and security prices fully reflect all relevant information as postulated by the EMH, any trading rule solely based on past data cannot yield above-average returns, as by the time the information is public the price adjustment has taken place. Trading based on technical analysis where the basic philosophy is that security prices tend to move in trends, such that the trading rules are based on past price movements, will not therefore be able to yield above-average returns (Reilly, 1989: 658, 245).

In contrast, the philosophy underlying fundamental analysis is that the intrinsic value of a security is determined by the underlying economic variables. Fundamental analysts analyse and estimate macro-economic prospects such as economic growth, inflation and interest rates and then identify industries that will gain most from these conditions. The fundamental analysts subsequently determine the intrinsic value of the companies within these industries, in order to identify and invest in those which are undervalued, in other words for which the market price is lower than the intrinsic value. It is possible for the market price and the intrinsic value of a security to differ but the market will eventually correct this discrepancy. Thus an analyst capable of making a better-than-average estimate of the intrinsic value will be able to make above-average profits.

\subsection{The constant growth model}

Initially, most of the empirical research on the EMH was done in terms of the random walk theory, which was based on empirical analysis without a theoretical foundation. Fama (1970) presented the first synthesis of the efficient market theory in terms of the fair game model. Samuelson (1965) and Mandelbrot (1963) showed that the fair game model is analytically equivalent to the expected present value theory of security valuation (also called the present value model). The now familiar expected present value model first presented by Smith (1925) is:

$$
P_{i . t}=\sum_{n=1}^{\infty} \frac{E\left[D_{i . t+n}\right]}{\left(1+k_{i}\right)^{n}} \text {. }
$$

The current share price can be solved from equation 1 by setting $t=0$ :

$$
P_{i .0}=\sum_{n=1}^{\infty} \frac{E\left[D_{i . n}\right]}{\left(1+k_{i}\right)^{n}} \bullet
$$

Equation 4 shows that the price of a security is equal to the present value of the expected future dividend receipts of the asset. In this formula, the expected capital gain realised upon the sale 
of the security is subsumed since its magnitude also depends on the present value of the expected future dividend stream. On the assumption that expected dividends grow at a constant rate, Gordon and Shapiro (1956) replaced the problem of forecasting an infinite number of future dividends with that of estimating a single expected growth rate $g$. This means that equation 4 can be written as:

$$
\mathrm{P}_{\mathrm{i} .0}=\sum_{\mathrm{n}=1}^{\infty} \frac{\mathrm{D}_{\mathrm{i}, 0}\left(1+\mathrm{g}_{\mathrm{i}}\right)^{\mathrm{n}}}{\left(1+\mathrm{k}_{\mathrm{i}}\right)^{\mathrm{n}}}
$$

where $P_{i, 0}$ is the price of security $i$ in period 0 ; $D_{i, 0}$ is the dividend in period $0 ; g_{i}$ is the expected growth rate of security $i$; and $k_{i}$ is the rate at which the dividends are discounted. By using the properties of the sum to infinity of a geometric series, equation 3 can be reduced to the constant growth model:

$$
P_{i, 0}=\frac{E\left(D_{i, 1}\right)}{k_{i}-g_{i}}=\frac{D_{i, 0}\left(1+g_{i}\right)}{k_{i}-g_{i}} \bullet
$$

Thus the equilibrium price of security $i$ is determined by its dividends $(D)$, the growth rate $(g)$ and the discount rate $(k)$.

Theoretically, the present value model asserts that security prices are determined by dividends and the discount rate. It follows trivially that any factor that influences the stream of cash flows or the discount rate will systematically influence stock prices. Since the seminal article by Chen et al. (1986), the influence of variables such as interest rates and inflation on the discount rate and of industrial production growth on the expected cash flows or dividends has been well established. In empirical studies, these and other variables are usually used to proxy the influence of dividends on stock prices. Jondeau and Nicolai (1993) have shown that only in the US do dividends directly explain stock prices, while in other countries dividends have to be replaced by proxies. In the literature, dividends are usually proxied by variables such as industrial production, unemployment or the state of the business cycle in empirical analyses (see e.g. Ansotegui \& Esteban, 2002 and Harasty \& Roulet, 2000).

The discount rate is determined by three factors: (i) the economy's real risk-free rate; (ii) the expected rate of inflation; and (iii) a risk premium (Reilly, 1989: 326). Investors want to be compensated for expected inflation, so that their money does not lose purchasing power over time. In addition, they want to receive the real risk-free rate to compensate them for the opportunity cost of parting with their money. According to the expectations hypothesis, the long-term interest rate on a security is the average of all the expected future short-term interest rates expected to prevail over the duration of the security. Since the expected future short-term interest rates are used to discount future returns in a present value model of stock prices, the long-term rate can be used as discount factor since it captures the expected short-term interest rates (see e.g. Harasty \& Roulet, 2000 and Zhou, 1996). Finally, a risk premium is added to the discount rate to compensate for the uncertainty regarding the expected returns of the security. The risk associated with investment includes several major sources of uncertainty, namely business risk, liquidity risk, exchange rate risk, interest rate risk, purchasing power risk, management risk, default risk and industry risk.

\section{4}

\section{Literature review}

Studies that model stock market prices or returns can be classified as either structural models that try to develop and estimate a model of the stock market, or studies that evaluate the relationship between the stock market and macro-economic variables.

\subsection{International studies}

Most studies that model stock prices are based on Gordon and Shapiro's constant growth model as theoretical basis. According to this model, security prices are equal to the present value of the future income stream of these securities, and hence stock prices are a function of future dividends and the discount rate. In empirical studies, dividends are often proxied by variables such as economic growth or industrial production, while the discount rate is specified as the long-term interest rate to which a risk premium is sometimes added. 
The existing stock market models can be divided into two categories, namely models of stock price levels and stock market returns. Studies in the first category are usually based on the present value model. It has been shown empirically that the long-term level of stock prices in developed countries is determined according to the present value model, in other words stock prices are determined by dividends (or a proxy thereof) and the discount rate (see e.g. Harasty \& Roulet, 2000; Ansotegui \& Esteban, 2002 and Yuhn, 1996). Since the seminal article by Chen et al. 1986, the influence of variables such as interest rates and inflation on the discount rate and of the economic growth on dividends has been well established. The short-term fluctuations around the long-term equilibrium level are influenced by short-term interest rates, exchange rates, the yield spread and foreign interest rates (see e.g. Harasty \& Roulet, 2000).

Studies in the second category have found the following variables significant in determining stock market returns: short-term interest rates (Lee, 1997 and Leung, Daouk \& Chen, 2000), expected inflation (Kaul, 1990), the yield spread (Campbell 1987, Black and Fraser 1995), inflation (Spyrou, 2001), economic growth (Leung et al., 2000), exchange rates (Fang, 2002) and the business cycle (Chen, 1991; Fama \& French, 1989; Perez-Quiros \& Timmerman, 1996).

\subsection{Structural models of the South African stock market}

Van Rensburg $(1995,1998,1999)$ made the largest contribution to the literature on modeling relationships between returns on the JSE and macro-economic variables. Van Rensburg (1995) estimated linear relationships between the Johannesburg Stock Exchange and four economic factors, namely the unexpected changes in the term structure, unexpected returns on the New York Stock Exchange, unexpected changes in inflation expectations and unexpected changes in the gold price. Van Rensburg's results indicated that all four factors significantly influence stock prices.
Van Rensburg (1998) used bivariate Granger causality tests and correlations to study relationships between stock market returns and macro-economic variables. He does not attempt to estimate a model for the stock market, but only causal relationships between the stock market and macro-economic variables. He tests three categories of variables, namely factors influencing the discount rate (such as various interest rates), factors influencing dividends (such as economic growth) and international factors.

In addition to returns on the Johannesburg Stock Exchange (JSE) overall index, Van Rensburg (1999) also analysed relationships between the returns on the industrial and gold indices of the JSE and several macro-economic variables. His results show that long-term interest rates, the gold and foreign reserve balance and the balance on current account have a significant influence on the returns of all three indices. In addition, the industrial index is influenced significantly by short-term interest rates and the Dow Jones industrial index, while the gold index is influenced significantly by the rand/US\$ exchange rate and the gold price.

Like Van Rensburg (1995, 1998, 1999), Barr (1990) tried to identify the macro-economic factors that influence returns on the JSE. Unlike Van Rensburg, however, Barr follows a factoranalytic approach and identifies the gold price, the short-term interest rate, foreign stock markets and local business confidence as factors that significantly influence returns on the JSE.

Jefferis and Okeahalam (2000) used cointegration and error correction techniques to model the stock markets of South Africa, Botswana and Zimbabwe. They followed an atheoretical approach, and used quarterly data for the period 1985 to 1995 . Their empirical results for South Africa indicated that real stock prices are positively related to the real exchange rate and real GDP, and negatively related to longterm interest rates. In the short term, real domestic long-term interest rates, US interest rates, the real exchange rate and domestic GDP influence the stock market.

Similar to the case of international studies, few studies have modelled the level of the South African stock market. Barr and Kantor (2002) 
developed and estimated a structural econometric model in which they attempt to capture the linkages between South African real and financial markets and the global economy, using co-integration techniques. Since their focus is on identifying and modelling the linkages between the different markets, their stock market equation reflects the main channels through which the South African stock market is influenced, rather than the fundamental factors driving it. In addition to an autoregressive term, their results show that the JSE is a positive function of foreign stock prices and commodity prices.

\section{5 \\ Empirical estimation}

The long-term and short-term behaviour of the stock market will be modelled separately, with the co-integration equation and the error correction model (ECM) respectively.

\subsection{Data}

The data for the South African gross domestic product (GDP), JSE all-share index (JSE), long-term $\left(\mathrm{R}_{\mathrm{L}}\right)$ and short-term interest rates $\left(R_{S}\right)$ and the gold price (Gold) were obtained from the South African Reserve Bank (www.reservebank.co.za). Data for US longterm interest rates $\left(\mathrm{R}_{1}^{\mathrm{us}}\right)$ and the Standard \& Poor 500 Index (SP500) were obtained from the Federal Reserve Bank of St. Louis (www.stlouisfed.org). Quarterly data were used from the third quarter of 1978 to the end of 2000. The construction of the discount rate (Discount) and the risk premium (Risk) are described below.

The discount rate comprises the real risk-free long-term interest rate, an inflation premium and a risk premium (the determination of the discount rate is described in section 3.2). The nominal yield on 10-year government bonds captures both the real interest rate and the inflation premium. However, this yield also includes a risk premium that rewards investors for taking on the additional risk of investing in South African bonds instead of US government bonds that are considered truly risk-free. Since this yield already includes a premium for the country risk, the additional risk premium included in the discount rate only has to capture the risk of investing in South African stocks rather than bonds, i.e. the equity premium.

Jagannathan et al. (2000) showed that the equity premium can be proxied by the sum of the dividend yield and expected dividend growth less the real bond yield. According to the IMF (2001), the expected dividend growth can by proxied by the growth in potential output. Following Barrel and Davis (2003), the growth in potential output was constructed by using a Hodrick Prescott filter on real economic growth to proxy dividend growth. Hence the discount rate in this study was constructed as the sum of the nominal yield on 10-year government bonds and the equity premium.

In many studies the risk premium is assumed to be constant (see e.g. Harasty \& Roulet, 2000). However, Firer and Bradfield (2002) have shown that South Africa's risk premium has declined over time. Barrel and Davis (2003) have shown that the risk premiums of six developed countries have also been timevarying. It would therefore be inappropriate to follow Harasty and Roulet (2000) in omitting the risk premium based on the assumption that it is constant. The risk premium (risk) attempts to capture the country risk of investing in South Africa and is therefore constructed as the excess returns on long-term South African government bonds relative to long-term US government bonds. 


\section{Figure 1}

The JSE overall index

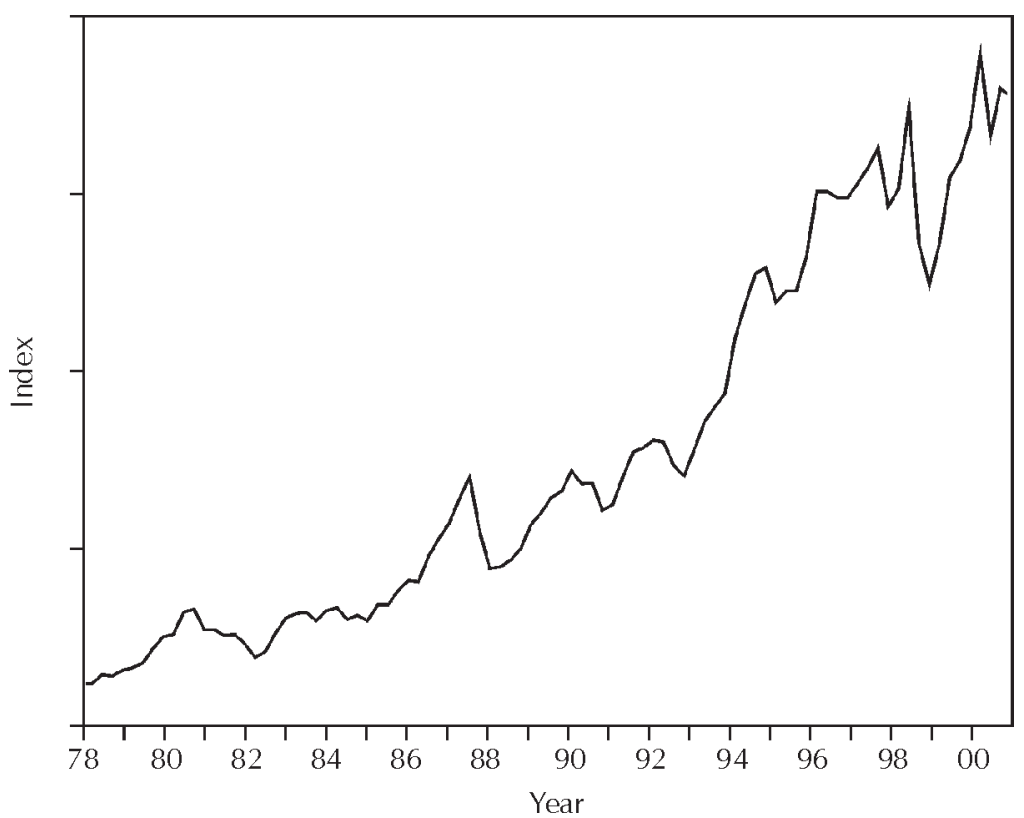

Source: South African Reserve Bank

Table 2

List of variables

\begin{tabular}{|l|l|}
\hline Name & Explanation \\
\hline JSE & JSE overall index \\
\hline GDP & Gross Domestic Product at current prices \\
\hline Discount & Constructed discount rate (see section 3.2) \\
\hline Gold & Gold price \\
\hline SP500 & Standard \& Poor 500 Index (S\&P500) \\
\hline R\$ & Rand/US\$ exchange rate \\
\hline$R_{S}$ & Short-term interest rate \\
\hline Risk & $\begin{array}{l}\text { Risk premium, defined as the difference between long-term interest rates in South Africa } \\
\text { and the US }\end{array}$ \\
\hline
\end{tabular}

Models that contain potentially non-stationary variables can result in a spurious regression, indicating statistically significant relationships where there are none. The statistical significance obtained from standard regression techniques with non-stationary variables is picking up the existence of contemporaneous correlation in the variables due to their trending over time, rather than a meaningful causal relationship between them. It is therefore vital to determine the order of integration of all the variables used in the econometric analysis, as this will determine the correct estimation technique to use.

In this study, the augmented Dickey-Fuller (ADF) and Phillips-Perron (PP) tests were used 
in conjunction with data plots to establish the order of integration of the variables. According to the results in the Appendix, the stock price index, GDP, the gold price, the Standard \& Poor 500 Index, the short-term interest rate, the rand/ US\$ exchange rate and the risk premium are integrated of order one.

\subsection{The co-integration equation}

According to the constant growth model (refer to section 3.2), stock prices are a function of (a proxy for) dividends and the discount rate. However, it has to be tested empirically whether this model holds for South Africa. If these variables are co-integrated, the co-integration vector will reflect the magnitudes of the impact of each variable on the long-term level of the stock market. In addition to the long-term cointegration equation, an error-correction model (ECM) will be estimated to capture the shortterm fluctuations of the stock market. This will evaluate whether and to what extent factors such as exchange rates, interest rates, contagion, foreign stock markets and the gold price influence the stock market in the short-term.

In the presence of non-stationary variables, ordinary least squares (OLS) are superconsistent if the variables are co-integrated, but the OLS coefficients are biased and the t- statistics have a non-standard distribution. Therefore the Fully-Modified OLS (FM-OLS) estimator and t-statistic of Phillips and Hansen (1990), which correct the bias of the OLS estimator and t-statistic, will be used instead. This FM-OLS estimator is super-consistent, asymptotically unbiased and asymptotically normally distributed. The adjusted t-statistic is asymptotically distributed standard normal.

\section{Table 3}

Co-integration equation

\begin{tabular}{lc|}
$\begin{array}{l}\text { Dependent Variable: } \log (J S E) \\
\text { Method: FM-OLS } \\
\text { Order of VAR: } 3\end{array}$ \\
\hline Variable & \\
Log(GDP) & \\
Discount rate & 0.866 \\
Constant & -0.012 \\
\end{tabular}

The results of the Johansen co-integration tests are presented in Table 3. Table 5 gives the results of the trace and eigenvalue tests, which indicate that the equation is co-integrated at a five per cent level of significance and that there is only one co-integration vector. The order of the VAR was determined on the basis of the Likelihood and the Akaike and SchwartzBayesian criteria (see Table 4).

\section{Table 4}

Test statistics and choice criteria for selecting the order of the VAR model

\begin{tabular}{|c|c|c|c|}
\hline Order & Log likelihood & Akaike & Schwarz Bayesian \\
\hline 4 & $\mathbf{2 2 9 . 5 0 9 0}$ & 193.5090 & 149.3308 \\
\hline 3 & 223.0076 & $\mathbf{1 9 6 . 0 0 7 6}$ & $\mathbf{1 6 2 . 8 7 3 9}$ \\
\hline 2 & 175.5390 & 157.5390 & 135.4499 \\
\hline 1 & 117.4193 & 108.4193 & 97.3749 \\
\hline 0 & -597.2638 & -597.2638 & -597.2638 \\
\hline
\end{tabular}


Table 5

Trace and Eigenvalue tests for co-integration

\begin{tabular}{|l|c|c|c|c|c|}
\hline Test & $\begin{array}{c}\text { Null } \\
\text { hypothesis }\end{array}$ & $\begin{array}{c}\text { Alternative } \\
\text { hypothesis }\end{array}$ & Statistic & $\begin{array}{c}\mathbf{9 5 \%} \\
\text { critical value }\end{array}$ & $\begin{array}{c}\mathbf{9 0 \%} \\
\text { critical value }\end{array}$ \\
\hline Trace & $\mathrm{r}=0$ & $\mathrm{r}>=1$ & $39.3256^{*}$ & 31.54 & 28.78 \\
\hline & $\mathrm{r}<=1$ & $\mathrm{r}>=2$ & 14.7101 & 17.86 & 15.75 \\
\hline & $\mathrm{r}<=2$ & $\mathrm{r}=3$ & 4.79810 & 8.070 & 6.500 \\
\hline Eigen value & $\mathrm{r}=0$ & $\mathrm{r}=1$ & $24.6155^{*}$ & 21.12 & 19.02 \\
\hline & $\mathrm{r}<=1$ & $\mathrm{r}=2$ & 9.91200 & 14.88 & 12.98 \\
\hline & $\mathrm{r}<=2$ & $\mathrm{r}=3$ & 4.79810 & 8.070 & 6.500 \\
\hline
\end{tabular}

* Reject null hypothesis on 5 per cent level of significance.

Both the trace and eigenvalue tests rejected the null hypothesis of no co-integration and confirmed the presence of a single cointegrating vector. This means that there is a co-integrated relationship between these variables and that the long-term relationship can be estimated using co-integration techniques.

Since the variables are co-integrated, the results of the co-integration equation in Table 3 can be interpreted. According to these results, the long-term level of the South African stock market is determined according to the constant growth model. The results show that a one per cent increase in gross domestic product (GDP) will cause a 0.866 per cent increase in the stock market, while a one unit increase in the discount rate will cause a decline of 0.012 per cent in the stock market. Since co-integration has been established and the co-integration vector estimated, an ECM can be estimated.

Table 6

Error correction model

\begin{tabular}{|c|c|c|c|c|}
\hline \multicolumn{5}{|c|}{$\begin{array}{l}\text { Dependent variable: } \Delta \log (\mathrm{JSE}) \\
\text { Method: Least squares }\end{array}$} \\
\hline Variable & Coefficient & Std. Error & t-Statistic & p-value \\
\hline$\Delta \log \left(J S E_{t-1}\right)$ & 0.262 & 0.067 & 3.922 & 0.000 \\
\hline Residual $_{\mathrm{t}-1}$ & -0.163 & 0.050 & -3.230 & 0.002 \\
\hline$\Delta \mathrm{LOG}($ Gold $)$ & 0.250 & 0.091 & 2.759 & 0.007 \\
\hline$\Delta \mathrm{LOG}(\mathrm{SP} 500)$ & 0.856 & 0.103 & 8.321 & 0.000 \\
\hline$\Delta R P$ & -0.045 & 0.009 & -4.834 & 0.000 \\
\hline$\Delta R P_{t-1}$ & 0.042 & 0.010 & 4.439 & 0.000 \\
\hline$\Delta \log \left(R \$_{t-1}\right)$ & 0.343 & 0.093 & 3.711 & 0.000 \\
\hline Constant & 0.001 & 0.018 & 0.058 & 0.954 \\
\hline$\Delta \log \left(R_{\mathrm{St}-1}\right)$ & -0.023 & 0.007 & -3.062 & 0.003 \\
\hline DUM00 & -0.124 & 0.017 & -7.509 & 0.000 \\
\hline DUM94 & 0.060 & 0.028 & 2.121 & 0.037 \\
\hline $\begin{array}{l}R^{2} \\
\text { Adjusted } R^{2} \\
\text { S.E. of regression }\end{array}$ & $\begin{array}{l}0.63 \\
0.58 \\
0.06\end{array}$ & $\begin{array}{l}\text { F-statistic } \\
\text { Prob(F-statistic) }\end{array}$ & & $\begin{array}{r}13.54 \\
0.000\end{array}$ \\
\hline
\end{tabular}




\subsection{The Short-term dynamics: An error correction model (ECM)}

In addition to the long-term co-integration equation, an error correction mechanism (ECM) can be estimated in order to capture the short-term or dynamic adjustment process to the long-term equilibrium. The estimation results of the ECM are reported in Table 6 .

The short-term dynamics of the stock market can be explained by short term interest rates, the rand/US\$ exchange rate, the Standard \& Poor 500 Index, the gold price, investor expectations and a risk premium. In many cases, the estimated coefficients of the ECM are not interpreted (see e.g. Du Toit, 1999; Koekemoer, 1999 and Du Toit and Moolman, 2004, as many of the variables enter the model in differenced form, which makes it difficult to interpret the relationships sensibly. In some sense the theory is differenced away, as very little is known about the relationship between the growth rates of any variables. However, in this study, the dependent variable of the ECM, the change in the log of the JSE, is equivalent to stock market returns. Following Kia (2003), it is therefore possible to interpret the estimated coefficients in the ECM. Kia (2003) interprets all the coefficients in the ECM. However, the coefficient of, for example, $\mathrm{D} \log (\mathrm{R} \$)$, should be interpreted as follows: a one unit increase in the growth of the exchange rate causes a 0.387 unit increase in stock market returns (the percentage change in the JSE). Even though we expect that a devaluation of the exchange rate should generally improve stock prices and returns ${ }^{3}$, it is difficult to reason about the exact relationship between the growth rate of the exchange rate and stock market returns. Therefore, unlike Kia (2003), only some of the coefficients in the ECM will be interpreted ${ }^{4}$.

The stock market of a small, open and financially integrated economy is expected to follow stock markets in the rest of the world (Kia, 2003). Lower returns on world stock markets are therefore expected to have a negative influence on returns on the South African stock market. The positive coefficient of foreign stock prices (measured by the
Standard \& Poor 500 Index) is consistent with this a priori expectation. This result is also consistent with the results of Kia (2003), Ammer and Mei (1996), Koutmos and Booth (1995), Kearney (1998), Francis and Leachman (1998); Ramchand and Susmel (1998) and Kia (2004).

According to the results, the risk premium has a negative impact on returns. Risk-averse investors require a higher discount rate for higher risk premiums. The discount rate is inversely related to share prices, and therefore the risk premium is expected to have a negative influence on stock market returns (Kia 2003) ${ }^{5}$.

The dummy variable Dum00, which takes on the value one in the last quarter of 1999 and zero otherwise, is capturing the lower returns at the end of the previous millennium when investors were selling their shares in anticipation of the so-called Y2K-problems. The second dummy variable, Dum94, takes on the value one during the year 1994 and zero otherwise, which captures the euphoria of South Africa's first democratic election during which the country experienced a significant increase in capital inflows ${ }^{6}$ and the volume and value of shares traded ${ }^{7}$ on the $\mathrm{JSE}^{8}$.

The model was subjected to rigorous diagnostic testing. Since all the variables in the ECM are stationary, the assumptions of classical regression analysis are fulfilled. The $\mathrm{R}^{2}$ value of 0.63 indicates that 63 per cent of the variation in the dependent variable is explained by the variation in the dependent variables, which is evidence of a very good fit. The Fstatistic of 13.54 indicates that the explanatory variables are jointly significant in explaining the stock market index. The t-statistics testing the significance of the individual coefficients indicate that all the coefficients are significantly different from zero and should therefore be included in the model.

Standard diagnostic tests can therefore be used to determine which variables should be included in the final specification of the ECM. The diagnostic test results reported in Table 7 indicate that the function passes all the relevant diagnostic tests. 
Table 7

Diagnostic tests

\begin{tabular}{|l|l|c|c|}
\hline Null hypothesis & Test & Test statistic & Probability \\
\hline Normality & Jarque-Bera & 0.266 & 0.875 \\
\hline Homoscedasticity & ARCH LM & 0.271 & 0.873 \\
\hline Homoscedasticity & White & 17.91 & 0.462 \\
\hline No Serial correlation & Breusch-Godfrey & 0.271 & 0.873 \\
\hline No Serial correlation & Durbin-Watson & 2.019 & \\
\hline No Misspecification & Ramsey Reset & 1.093 & 0.579 \\
\hline
\end{tabular}

6

\section{Conclusion}

In this paper, a structural model for the South African stock market has been developed and estimated. This model makes three important contributions to the literature. Firstly, the model gives empirical evidence on the importance of fundamentals in determining South African stock prices. The so-called 'contagion' effect between international stock markets has received considerable attention in recent literature, especially since the emerging market crises. However, if a stock market is found to be driven in the long term by fundamental domestic factors, it means that contagion influences only short-term fluctuations and not the long-term level or intrinsic value of the stock market. The results of this study showed that the long-term level of the South African stock market is determined according to the expected present value model, which means that it is driven in the long term by economic fundamentals. In the short term, the JSE reacts to changes in international stock markets, although these impacts are temporary.

A second contribution of the econometric model is that it has evaluated the relationships between the stock market and macro-economic variables. This is an important contribution to the general understanding of the functioning of the stock market as well as the relationships between the stock market and macro-economic variables. According to the results, the longterm level of share prices is determined by discounted future dividends. In addition, the short-term fluctuations are caused by short-term interest rates, the rand/US\$ exchange rate, the Standard \& Poor 500 Index, the gold price and a risk premium.

Finally, the model can be used for forecasting the JSE. It can also be used by investors for designing trading rules based on structural relationships, which should improve profits in the long-term.

\section{Endnotes}

1 The views expressed in this paper are those of the author(s) and should not be attributed to Standard Bank.

2 The AltX is similar to the AIM exchange in the UK, which also lists small growth companies. More than 850 companies have been listed on the AIM exchange, raising more than US $\$ 10$ billion since it opened in 1995.

3 For example, during 2002, the total value of trading on the JSE was R808,662 million, of which the value of foreign trading was R419,066 (www.jse.co.za).

4 Specifically, all the coefficients except those of fluctuations in the gold price, in shortterm interest rates and in the exchange rate are interpreted.

5 Many of the biggest firms listed on the JSE are mining-related companies which export a substantial part of their production. A depreciation of the rand lowers the relative price of South African exports and hence causes an increase in the demand for 
exports. This in turn improves the profits and share prices of these companies. For example, the earnings of Anglo American, the biggest company listed on the JSE, fall by US $\$ 124$ million if the rand appreciates 10 per cent against the US dollar (McKay, 2003).

6 South Africa had a net capital inflow of $\mathrm{R} 4,359$ million in 1994, compared to a net capital outflow of R5,669 million in 1993 (www.reserve-bank.co.za).

7 The volume of shares traded on the JSE increased from 303.8 million in 1993 to 444.25 million in 1994 (www.reservebank. co.za). The value of shares traded on the JSE almost doubled from R2,843.92 million in 1993 to R5,204.33 million in 1994 (www.reservebank.co.za).

8 The Japan Securities Dealers Association gave the JSE 'designation status' in December 1994, which means that the JSE was then considered an 'appropriate' market for Japanese investors (Brooks et al., 1997). The JSE was included in the Morgan Stanley Index from March 1995, while it was included in the IFC Emerging Markets Global and Investable Indices from March 1995 (Brooks et al., 1997).

\section{References}

1 AMMER, J. \& MEI, J. (1996) "Measuring international economic linkages with stock market data", The Journal of Finance, LI (5): 1743-63.

2 ANSOTEGUI, C. \& ESTEBAN, M.V. (2002) "Co-integration for market forecast in the Spanish stock market", Applied Economics, 34(7): 843-57.

3 BARR, G. \& KANTOR, B. (2002) "The South African economy and its asset markets - An integrated approach", South African Journal of Economics, 70(1): 53-77.

4 BARREL, R. \& DAVIS, E.P. (2003) "Shocks and shock absorbers: The international propagation of equity market shocks and the design of appropriate policy responses", National Institute of Economic and Social Research, Working paper.
5 BLACK, A. \& FRASER, P. (1995) "U.K. stock returns: Predictability and business conditions", The Manchester School, Supplement 1995: 85102.

6 CAMPBELL, J.Y. (1987) "Stock returns and the term structure", Journal of Financial Economics, 18: 373-99.

7 CHEN, N-F.; ROLL, R. \& ROSS, S.A. (1986)

"Economic forces and the stock markets",

Journal of Business, 59: 383-403.

8 CHEN, N-F. (1991) "Financial investment opportunities and the macro-economy", Journal of Finance, XLVI (2): 529-44.

9 DU TOIT, C.B. (1999) "A supply-side model of the South African economy: Critical policy implications", unpublished thesis, University of Pretoria: Pretoria.

10 DU TOIT, C.B. \& MOOLMAN, H.C. (2004) "A neoclassical investment function for South Africa”, Economic Modelling, 21(4): 647-60.

11 FAMA, E.F. (1970) "Efficient capital markets: A Review of theory and empirical work", Journal of Finance, 25 (2): 383-417.

12 FAMA, E.F. \& FRENCH, K.R. (1989) "Business cycle conditions and expected returns on stocks and bonds", Journal of Financial Economics, 25: 23-49.

13 FANG, W. (2002) "The effects of currency depreciation on stock returns: Evidence from five East Asian economies", Applied Economics Letters, 9 (3): 195-9.

14 FIRER, C. \& BRADFIELD, D. (2002) "On the market risk premium”, Journal for Studies in Economics and Econometrics, 26(2): 69-80.

15 FRANCIS, B.B. \& LEACHMAN, L.L. (1998) "Superexogeneity and the dynamic linkages among international equity markets", Journal of International Money and Finance, 17: 475-92.

16 GORDON, M.J. \& SHAPIRO, E. (1956) "Capital equipment analysis: The required rate of profit", Management Science, October 53-61.

17 HARASTY, H. \& ROULET, J. (2000) "Modeling stock market returns", Journal of Portfolio Management, 26 (2): 33.

18 IMF (International Monetary Fund) (2001) "Asset prices and the business cycle", in World Economic Outlook, April, 101-49.

19 JAGANNATHA, R.; MCGRATTAN, E. \& SCHERBINA, A. (2000) "The declining US risk premium”, Federal Reserve Bank of Minneapolis Quarterly Review, 24/4: 3-19.

20 JONDEAU, E. \& NICOLAI, J.P. (1993) "Modelisation du prix des actifs financiers", 
Document d'Etude, Groupe Caisse des Depots, Service des Etudes Economiques et Financieres, 1993-16/F: 1-85.

21 JEFFERIS, K.R. \& OKEAHALAM, C.C. (2000) "The impact of economic fundamentals on stock markets in southern Africa". Development Southern Africa, 17(1): 23-51.

22 KAUL, G. (1990) "Monetary regimes and the relation between stock returns and inflationary expectations", Journal of Financial and Quantitative Analysis, 15: 307-21.

23 KEARNEY, C. (1998) "The causes of volatility in a small, internationally integrated stock market: Ireland, July 1975-June 1994", The Journal of Financial Research, XXI(1): 85-104.

24 KIA, A. (2003) "Forward-looking agents and macroeconomic determinants of the equity price in a small open economy", Applied Financial Economics, 13(1): 37-54.

25 KOEKEMOER, R. (1999) "Private consumption expenditure in South Africa: the role of price expectations and learning", unpublished doctoral thesis, University of Pretoria: Pretoria.

26 KOUTMOS, G. \& BOOTH, G.G. (1995) "Asymmetric volatility transmission in international stock markets", Journal of International Money and Finance, 14(6): 747-62.

27 LEE, W. (1997) "Market timing and short-term interest rates", Journal of Portfolio Management, 23(3): 35 .

28 LEUNG, M.T.; DAOUK, H. \& CHEN, A.S. (2000) "Forecasting stock indices: A comparison of classification and level estimation models", International Journal of Forecasting, 16: 173-90.

29 MANDELBROT, B. (1963) "The variation of certain speculative prices", Journal of Business, 36: 394-419.

30 PEREZ-QUIROS, G. \& TIMMERMANN, A. (1996) "On business cycle variation in the mean, volatility and conditional distribution of stock returns", UCSD Discussion Paper, 96-13.
31 PHILLIPS, P.C.B. \& HANSEN, B.E. (1990) "Statistical inference in instrumental variables regression with i(1) processes", The Review of Economic Studies, 57: 99-125.

32 RAMCHAND, L. \& SUSMEL, R. (1998) "Volatility and cross correlation across major stock markets", Journal of Empirical Finance, 5: 397-416.

33 REILLY, F.K. (1989) Investment Analysis and Portfolio Management, The Dryden Press: Florida.

34 SAMUELSON, P.A. (1965) "Proof that properly anticipated prices fluctuate randomly", Industrial Management Review, 6: 41-9.

35 SPYROU, I.S. (2001) "Stock returns and inflation: evidence from an emerging market", Applied Economics Letters, 8: 447-50.

36 VAN RENSBURG, P. (1995) "Economic forces and the Johannesburg Stock Exchange: A multifactor approach", De Ratione, 9(2): 45-63.

37 VAN RENSBURG, P. (1998) "Economic forces and the Johannesburg Stock Exchange", unpublished doctoral thesis, University of Natal: Natal.

38 VAN RENSBURG, P. (1999) "Macroeconomic identification of candidate APT factors on the Johannesburg Stock Exchange", Journal for Studies in Economics and Econometrics, 23(2): 27-53.

39 VAN ZYL, C.; BOTHA, Z. \& SKERRITT, P. (2003) Understanding South African Financial Markets, Van Schaik: Pretoria.

40 YUHN, K.-H. (1996) "Stock price volatility: Tests for linear and non-linear co-integration in the present value model of stock prices", Applied Financial Economics, 6(6): 487-94.

41 ZHOU, C. (1996) "Stock market fluctuations and the term structure. Board of governors of the federal reserve system", Finance and Economics Discussion Series: 96/03. 
Table A1

Augmented Dickey-Fuller and Phillips-Perron tests for non-stationarity levels

\begin{tabular}{|c|c|c|c|c|c|}
\hline Series & Model & Lags & $t_{\ell} t_{m r^{\prime}} t$ & $f_{3^{\prime}} f_{1}$ & PP (3 lags) \\
\hline $\log (J S E)$ & $\begin{array}{l}\text { Trend } \\
\text { Constant } \\
\text { None }\end{array}$ & $\begin{array}{l}1 \\
1 \\
1\end{array}$ & $\begin{array}{c}-4.356^{* * *} \\
--1.720 \\
1.911\end{array}$ & $\begin{array}{l}7.84 \\
2.98\end{array}$ & $\begin{array}{c}-3.88 * * \\
* 1.729 \\
2.24\end{array}$ \\
\hline $\log (G D P)$ & $\begin{array}{l}\text { Trend } \\
\text { Constant } \\
\text { None }\end{array}$ & $\begin{array}{l}4 \\
3 \\
4\end{array}$ & $\begin{array}{l}-1.26 \\
-4.31^{* * *} \\
2.23\end{array}$ & $\begin{array}{l}4.44 \\
6.33\end{array}$ & $\begin{array}{l}-0.48 \\
-4.14^{* * *} \\
12.13\end{array}$ \\
\hline Log (Gold) & $\begin{array}{l}\text { Trend } \\
\text { Constant } \\
\text { None }\end{array}$ & $\begin{array}{l}0 \\
0 \\
0\end{array}$ & $\begin{array}{l}-2.59^{* *} \\
-2.60 \\
-2.74^{*}\end{array}$ & $\begin{array}{l}7.81 \\
6.78\end{array}$ & $\begin{array}{c}-3.62^{* *} \\
-2.56 \\
2.47\end{array}$ \\
\hline Log (S\&P500) & $\begin{array}{l}\text { Trend } \\
\text { Constant } \\
\text { None }\end{array}$ & $\begin{array}{l}1 \\
0 \\
0\end{array}$ & $\begin{array}{r}-2.45 \\
0.52 \\
5.01\end{array}$ & $\begin{array}{l}2.70 \\
0.72\end{array}$ & $\begin{array}{r}-2.47 \\
0.43 \\
4.64\end{array}$ \\
\hline $\mathrm{R}_{\mathrm{S}}$ & $\begin{array}{l}\text { Trend } \\
\text { Constant } \\
\text { None }\end{array}$ & $\begin{array}{l}1 \\
1 \\
1\end{array}$ & $\begin{array}{l}-2.82 \\
-2.92 \\
-0.71\end{array}$ & $\begin{array}{r}9.83 \\
14.91\end{array}$ & $\begin{array}{l}-2.26 \\
-2.39 \\
-0.61\end{array}$ \\
\hline $\log (\mathrm{R} \$)$ & $\begin{array}{l}\text { Trend } \\
\text { Constant } \\
\text { None }\end{array}$ & $\begin{array}{l}3 \\
3 \\
3\end{array}$ & $\begin{array}{r}-2.76 \\
-0.35 \\
1.86\end{array}$ & $\begin{array}{l}3.09 \\
1.83\end{array}$ & $\begin{array}{l}-2.32 \\
0.012 \\
2.87\end{array}$ \\
\hline Rp & $\begin{array}{l}\text { Trend } \\
\text { Constant } \\
\text { None }\end{array}$ & $\begin{array}{l}0 \\
0 \\
0\end{array}$ & $\begin{array}{l}-2.087 \\
-1.35 \\
-0.21\end{array}$ & $\begin{array}{l}2.21 \\
1.81\end{array}$ & $\begin{array}{l}-2.20 \\
-1.34 \\
-0.19\end{array}$ \\
\hline
\end{tabular}

*/**/*** Significant at a 10 per cent/5 per cent/1 per cent level.

Table A2

Augmented Dickey-Fuller and Phillips-Perron tests for non-stationarity, first differenced

\begin{tabular}{|l|l|c|c|c|c|}
\hline Series & Model & Lags & $\boldsymbol{t}_{\boldsymbol{\prime}} \boldsymbol{t}_{\boldsymbol{m}^{\prime}} \boldsymbol{t}$ & $\boldsymbol{f}_{\mathbf{z}^{\prime}} \boldsymbol{f}_{\mathbf{1}}$ & $\boldsymbol{P P}$ (3 lags) \\
\hline$\Delta \log (\mathrm{JSE})$ & Trend & 0 & $-7.86^{* * *}$ & 30.90 & -7.81 \\
& Constant & 0 & $-7.81^{* * *}$ & 61.07 & -7.77 \\
& None & 0 & $-7.28^{* * *}$ & & -7.28 \\
\hline$\Delta \log (\mathrm{GDP})$ & Trend & 2 & $-6.56^{* * *}$ & 23.99 & $-9.72^{* * *}$ \\
& Constant & 3 & $-2.95^{* *}$ & 17.38 & $-8.29^{* * *}$ \\
& None & 3 & -1.101 & & $-2.61^{* * *}$ \\
\hline$\Delta \log ($ Gold $)$ & Trend & 0 & $-8.44^{* * *}$ & 35.6 & $-8.43^{* * *}$ \\
& Constant & 0 & $-8.30^{* * *}$ & 68.8 & $-8.29^{* * *}$ \\
& None & 0 & $-7.69^{* * *}$ & & $-7.73^{* * *}$ \\
\hline$\Delta \log (\mathrm{SP} 500)$ & Trend & 0 & $-7.88^{* * *}$ & 31.25 & $-7.86^{* * *}$ \\
& Constant & 0 & $-7.93^{* * *}$ & 62.83 & $-7.91^{* * *}$ \\
& None & 0 & $-6.45^{* * *}$ & & $-6.55^{* * *}$ \\
\hline$\Delta \mathrm{R}_{\mathrm{S}}$ & Trend & 0 & $-5.98^{* * *}$ & 17.89 & $-5.94^{* * *}$ \\
& Constant & 0 & $-5.96^{* * *}$ & 35.54 & $-5.93^{* * *}$ \\
& None & 0 & $-5.99^{* * *}$ & & $-5.97^{* * *}$ \\
\hline$\Delta \log (\mathrm{R} \$)$ & Trend & 2 & $-4.12^{* * *}$ & 19.86 & $-8.366^{* * *}$ \\
& Constant & 2 & $-4.14^{* * *}$ & 26.77 & $-8.39^{* * *}$ \\
& None & 2 & $-3.21^{* * *}$ & & $-7.48^{* * *}$ \\
\hline$\Delta \mathrm{Rp}$ & Trend & 0 & $-8.46^{* * *}$ & 35.83 & $-8.41^{* * *}$ \\
& Constant & 0 & $-8.51^{* * *}$ & 72.31 & $-8.46^{* * *}$ \\
& None & 0 & $-8.53^{* * *}$ & & $-8.48^{* * *}$ \\
\hline
\end{tabular}

